\title{
SIMIENTE DE ESTHER SELIGSON, ESCRITURA HÍBRIDA DE LUZ Y SOMBRA
}

\section{Berenice Romano Hurtado}

Universidad Autónoma del Estado de México

brhurtado@gmail.com

Resumen: Esther Seligson es una escritora mexicana que no limitó su escritura a los cánones de los géneros literarios. Deconstruyó formas, mitos y lenguaje; su poética responde a esa combinación de géneros. Simiente es el resultado de una experiencia trágica; en busca de algún consuelo y de la comprensión del evento, Seligson compone una obra peculiar en la que conviven diversos géneros y tipos de discurso, como una forma de armar con fragmentos la imagen del hijo perdido.

Palabras clave: híbrido, lenguaje, umbral, autobiografía, muerte.

\begin{abstract}
Esther Seligson is a Mexican writer who did not confine her writing to the canons of literary genres. She deconstructed forms, myths and language; her poetics responds to that combination of genres. Simiente is the result of a tragic experience; in pursuit of some sort of comfort and understanding of the event, Seligson composes a unique work in which diverse genres and types of discourse coexist, as a way of building the image of the lost son through fragments.
\end{abstract}

Keywords: hybrid, language, threshold, autobiography, death.

DOI: $\underline{\text { htps://doi.org/10.24029/lejana.2017.10.168 }}$

Recibido: el 30 de junio de 2017

Aceptado: el 29 de septiembre de 2017

Publicado: el 4 de noviembre de 2017 
Desovillo tu voz en mi escritura

y de alguna manera se apacigua mi dolor mas no así la pena

Esther Seligson

En 2003, Adrián Joskowicz, el hijo menor de la escritora mexicana Esther Seligson, se suicidó frente a ella tirándose de la ventana de su departamento. Simiente es la obra que resulta de esa dolorosa experiencia.

Esther Seligson trabajó casi todos los géneros, curiosamente, a pesar de estar dentro del ambiente teatral, nunca escribió un texto dramático. Sin embargo, la mayoría de su obra está imbuida por el tono y los recursos de la representación escénica. Seligson fue una lectora y estudiosa juiciosa; sus intereses fueron muchos y diversos, lo que la convirtió en una escritora excepcional. La refiguración de mitos, el tratamiento de temas en su prosa, los ensayos sobre poesía, entre otros, hicieron que su escritura se fuera nutriendo no solo de la variedad de temas que trataba sino de los géneros que le gustaba leer. Su escritura, en este sentido, se liberó de las formas tradicionales y dio paso a una poética que se caracteriza por la convivencia de distintos géneros en un mismo espacio textual.

Simiente se escribió en 2004, y se publicó en un volumen del Fondo de Cultura Económica de 2010, al lado de Negro es su rostro. Aunque en este último también se trabaja el duelo por la muerte del hijo, es Simiente la que representa esta muerte en sí. Con los diversos registros de la escritura de Seligson, y la "intervención” de Adrián con sus dibujos, cartas y extractos de su diario, el libro contiene la presencia del hijo, narra su muerte y la refigura desde distintas perspectivas.

La escritura de Seligson no es convencional desde ningún aspecto. Su interés por distintas culturas y religiones, su conocimiento de varios idiomas, su estancia en diversos países, desembocan en un abanico de temas y géneros literarios que definen la poética ${ }^{1}$ de esta autora mexicana.

Acerca de Simiente, Adriana del Moral Espinosa escribe que "es uno de sus libros más personales. Reproduce partes del diario de su hijo, cartas y poemas de Seligson. Es una obra dolorosa, intensa y profundamente honesta, escrita tras el suicidio de Adrián" (2010, en línea). En este libro, cada registro forma una idea que se encadena con el resto de discursos en un entramado concéntrico alrededor de la figura de Adrián Joskowicz Seligson. El crítico Stephen Kock explica la literatura híbrida como una compilación de fragmentos; encuentra un típico ejemplo en las obras que combinan autobiografía, notas, confesiones de diario, poemas en prosa, meditaciones, discurso crítico; textos que no son un mero pastiche, sino una unidad que toma su fuerza precisamente de esa diversidad (en Noguerol, 1999: 239); esta mezcla de discursos es la que configura Simiente. Una de las constantes en la literatura híbrida son estos rasgos autobiográficos que señala Kock. A su vez, Francisca Noguerol admite que "las [literaturas] misceláneas presentan en muchos casos un carácter autobiográfico, que confiere

\footnotetext{
${ }^{1}$ Seligson es una autora que se distinguió por haber desarrollado una escritura peculiar; fue una mujer estudiosa, intelectualmente inquieta, que supo aglutinar en su obra un conocimiento diverso, y a veces disímil, que la presentó en su momento como escritora de culto. Su poética representa esa textualidad plural no solo en sus temas, sino en sus formas narrativas. La libertad que se concedió para reelaborar mitos y fusionar distintos géneros literarios distingue su literatura y la presenta como una que no se ajusta a términos o géneros convencionales.
} 
unidad al conjunto a partir del "yo" autorial" (1999: 244). En este artículo, me interesa subrayar que el escrito de Seligson se apega a una forma de relato de vida posmoderno. Como pretendo señalar en el desarrollo, Simiente es un texto en el que lo híbrido funciona como partícula estructural de todos sus niveles. La poesía autobiográfica, como registro híbrido, enmarca esos estratos en los que el sujeto fragmentado, los personajes desdoblados, la différance como recurso en la escritura $\mathrm{y}$, en general, las formas mixtas como fundamento poético en la autora, tienden puentes para entramar una propuesta literaria original.

Simiente es, fundamentalmente, un texto de vida. En él, cada registro literario no solo ensaya una forma de escritura; no es un experimento literario, sino un cúmulo de textualidades con las cuales explorar al hijo: "Hoy me vacío en estas páginas en tu busca" (165), ${ }^{*}$ dice Seligson. La diversidad de formas de escritura representa una pluralidad de miradas alrededor de la muerte de Adrián, para, continúa la autora, "estructurar el caos tu caos lo amorfo vulnerable arquitectura cuerpo vaso roto tu fragilidad en busca de palabras simiente de luz" (149-150).

\section{Poesía híbrida y sus marcas textuales}

Establecer el surgimiento de géneros nuevos termina con el movimiento de lo híbrido en los términos en que se plantean en este escrito. Es decir, como forma organizativa que presenta en un mismo espacio textual diversas formas de discurso que se interrelacionan y se reflejan entre sí. La autoficción es una de estas representaciones híbridas; en ella, la narración ficcional y los elementos biográficos se fusionan bajo parámetros particulares. Hablar de autoficción en Simiente resulta problemático y hasta cierto punto reductivo, sin embargo, entre las muchas reflexiones que han surgido en torno a este género, están las que se concentran en aspectos estructurales que me interesa retomar, porque los encuentro en la organización híbrida del texto de Seligson.

Arnaud Schmitt se refiere a una poética cognitiva al explicar el recurso de la hibridez textual. Comenta que "el desplazamiento de un campo a otro o en el interior de un campo consiste en un «push» o un «pop», términos que implican a la vez la idea de un desplazamiento repentino pero también la necesidad de una reorientación, de un reajuste deíctico" (2014: 53), es decir, "atribuir otro referente a un pronombre personal que ya contaba con uno" (2014: 53). Refiere a un "yo" inestable, como el de Simiente, que pasa de ser el personaje-madre a ser la poeta, la mujer o, tal vez, la escritora misma que firma el texto. En el caso de la poesía, el "discurso factual”, que propone Marie-Laure Ryan (1991: 30), no es tal y supone otra serie de diversos discursos e imágenes que aluden a ciertas referencias biográficas, pero que no se presentan en el texto como un discurso revelado. No hay una correspondencia directa entre mundo de ficción y mundo poético, sino que lo híbrido, que carga además con un discurso visual, posibilita un mayor número de estratos textuales.

Como texto híbrido, en Simiente, cada categoría discursiva no representa lo que tradicionalmente se considera un poema o un cuento, por ejemplo, sino que resignifica su función. Por ello, aunque el epígrafe no es un género en sí mismo, la presencia que ocupa en

\footnotetext{
* Todas las citas de la obra de Seligson corresponden a la misma edición; solo se colocará frente a cada una el número de página de la que proceden.
} 
el texto de Seligson obliga a mirarlo de cerca. Igual que en otro tipo de discursos, los epígrafes con los que nutre su propia escritura concentran una idea que parece iterativa a lo largo del libro. Es decir, cada epígrafe, como partícula de un texto fuera del texto, se vincula entre sí a lo largo de Simiente como palpitaciones que saltan al comienzo de cada poema para reforzar tanto su propia presencia como la del resto de la escritura. En este sentido, destaco que

El proemio del libro se inicia con un epígrafe de Charles Simic: "Cada fragmento contiene dentro de sí mismo la posibilidad de revelar el significado del mundo como totalidad", (Seligson, 2010: 167) porque Simiente está hecha de pedazos: de los poemas de Seligson, del diario y los dibujos de Adrián, de la memoria hecha prosa. Y con esas piezas la escritora configura la representación más dolorosa; la exhibición, la exposición del hijo ausente. En este exordio, aglutina los trozos que en veinticuatro momentos textuales van a recobrar al hijo, para "mirarse a pedacitos hasta reconstruir la imagen completa." (Romano, 2017: 93)

En el apartado IV se encuentra el poema "Simiente", que se abre con un epígrafe de María Zambrano: "Quien pretende ser absolutamente acaba sintiéndose nada dentro de una resistencia sin fronteras" (Seligson, 2010: 151), que perfila la insuficiencia de un cuerpo que empuja a "erradicar lo externo refugio seminal [para alcanzar un] tiempo de luz" (157). El libro alterna los poemas y la prosa-poesía de Seligson con el diario, los dibujos y las cartas de Adrián. Los epígrafes encabezan los poemas y entre ellos guardan unidad temática, igual que con el resto de los discursos. De esta forma, el texto está fragmentado solo en apariencia, ya que en realidad está hecho de puntos en los que cada trozo literario confluye. El epígrafe, además de dar un aglutinado temático sirve de barrera que separa visualmente los textos en variadas escenas que son las que configuran la unidad de la obra. En este sentido, se puede decir que Simiente reelabora el mismo tema (la culpa frente a la muerte del hijo) en varios géneros, y que estos a su vez fungen aquí como espacios de representación de una identidad.

En relación con la teatralidad y el viaje como otra de sus pasiones en la escritura, Seligson señaló que

Al haber sido toda mi vida una apasionada del teatro, que es lo más efímero, lo más invisible que hay, cada función es, también, una especie de viaje. En este momento, a punto de cumplir 66 años, se me ocurre que mi obsesión por la fugacidad, ese nomadismo, es como una ilusión teatral, una especie de no sentir que envejeces, no sentir que echas raíces, sentirte libre; una libertad aunque sea ficticia, pero que te permite mover, sentir que puedes disponer de tu tiempo, de tu cuerpo, de tu mente, de todo, libremente. (Yaniret, 2007: en línea) ${ }^{2}$

Esta libertad es la que a su vez la lleva a no someterse a los cánones genéricos. Su propia existencia es la mezcla de muchos estímulos y experiencias de vida, y cada uno de ellos, a su vez, supone otras bifurcaciones. La traducción, que tanto ensayó, es otra forma de lo híbrido; híbridos son su espiritualidad y su vida nómada, en las que se mezclan lo judío, lo indú, la astrología y demás posturas ideológicas que atraviesan su obra.

\footnotetext{
${ }^{2}$ Para revisar la presencia del teatro en la obra de Esther Seligson, cfr. Berenice Romano Hurtado (2017): "De persona y personajes: dramaturgia y representación en la escritura de Esther Seligson". Esther Seligson. Fugacidad y permanencia. Eds. Luzelena Gutiérrez de Velasco Romo y Ana Rosa Domenella. México, Universidad Autónoma de México: 87-101. En imprenta.
} 
A manera de una tragedia, Simiente narra desde distintas perspectivas y con el tono solemne del género el camino que lleva al héroe (Adrián) a errar —a la hamartía ${ }^{3}$ que implica su crimen - para encontrarse con un destino fatal. En esta analogía, los epígrafes son el coro de voces que dan al lector el "argumento" de este texto. Con ellos, Seligson invita a escena a distintos escritores, sobre todo poetas, para que desde su estilo y su discurso nutran los poemas que ella, frente al mar de Ashkelón, concibió para Adrián. Cada uno, así, fuera de su contexto, es un poema en sí mismo que preludia la escritura de Esther. Tanto en lo que esos versos ajenos dicen, como en su proceder al invitarlos a su escritura, Seligson reúne y exhibe contrarios, la totalidad del mundo que es, a su vez, un cúmulo de significados que se debe descifrar.

En el poema "Días de polvo" abre con Miguel Torga: "A gente entende pouco do semelhante. Cada um de nos é um enigma que a maior parte das vezes fica por descifrar" (144). Por eso se escribe Simiente, para comprender y tratar de explicar la muerte. Para rearmar al hijo y probar mirarlo como por primera vez, con curiosidad, con deseo de interpretarlo, de que se deje leer. Cita a Georges Séféris: "Comment rassembler/Les milles infimes débris/De chaque homme?"5 (159). En los epígrafes se deja ver, a veces de forma implícita otras más evidente, la culpa que la narradora, en el papel de una madre doliente, siente por la muerte del hijo. De forma parecida, de Enriqueta Ochoa Seligson reproduce lo siguiente: "y me duele en los nervios/no haberte amado todo lo/que necesitas" (178).

Este coro de voces fuera del texto es el preludio que da paso al resto de los escritos; al camino de redes discursivas que, cuenta Seligson, germinó frente al mar: "un mar de invierno con tres días y tres noches de tormenta furiosa [...]. Ahí se gestó Simiente, sin ese mar furioso no hubiera nacido. Hay una furia debajo de la superficie que es tu propia furia, tu propio dolor y tu propia rabia [...]" (Abelleyra, 2004: 1). ${ }^{6}$

Hans-Gerog Gadamer considera que "lo trágico es un fenómeno fundamental, una figura de sentido, que en modo alguno se restringe a la tragedia o a la obra de arte trágica en sentido estricto, sino que puede aparecer también en otros géneros artísticos" (2007: 174). Para él, la esencia de lo trágico está en lo que llama la teoría del juego trágico y en el efecto que produce en el espectador. El juego refiere a la representación que implica toda manifestación estética y que en el caso de la tragedia involucra al oyente de una forma particular. En cualquier expresión artística, el juego es la pura realización, es decir, un desarrollo estético en sí mismo; pero en la representación dramática hay un llamado para que el espectador participe. Simiente es un conglomerado de discursos, una mezcla de géneros que no supone un caos, sino un entramado complejo, ${ }^{7}$ no apto para cualquier lector. De ahí que se

\footnotetext{
${ }^{3}$ En La Poética, Aristóteles usa el término "hamartía" para hablar del "error trágico" que no puede ser eludido por el héroe y que detona el desarrollo de la tragedia.

4 "Entendemos poco del semejante. Cada uno de nosotros es un enigma que la mayor parte del tiempo debemos descifrar" (La traducción es la nuestra).

5 “Cómo reunir / los miles de ínfimos fragmentos / de cada hombre?” (La traducción es la nuestra).

${ }^{6}$ Seligson se va a Jerusalén después de la muerte de Adrián. Aunque en este caso lo hace motivada por la tragedia, viajar es parte de su esencia y, por ende, de su poética. Dijo en una ocasión: "Sentirte extranjero en cada ciudad en la que vives te permite un contacto más emotivo" (Yanireth, 2007). En esa emotividad, multiplicada por la pérdida, concibe Simiente.

${ }^{7}$ En este sentido, Seligson siempre se declaró intolerante frente a lectores que no fueran profesionales; sus textos no son fáciles, por lo tanto, según sus propias palabras, no son para cualquiera. Afirmó, en una entrevista con Miguel Ángel Quemain que "La literatura, y que me perdonen, no está escrita para los ignorantes, lo siento
} 
puede afirmar que la tragedia, que parece ser esta obra, apela a una audiencia más activa que sea capaz de hilar las partes que la componen. Simiente, por otro lado, empuja al lector a reconocerse, a experimentar una catarsis en la que se ve "sacudido por la desolación y el estremecimiento [que] representa un doloroso desdoblamiento" (Gadamer, 2007: 177).

Aunque es difícil separar en géneros los textos de esta obra, la forma, dividida en versos, permite saber que hay nueve poemas intercalados con otro discurso que, a pesar de tener la apariencia de prosa, se distingue porque no se divide en versos y no tiene signos de puntuación, lo que ofrece posibilidades de lectura que lo podrían aproximar tanto a la narrativa como al poema libre. A cada uno de estos nueve poemas ("Días de polvo", "Simiente", "Ella, Nadine", "Retorna en el viento", "Tus ojos eran solo plegaria", "Petición sumaria", "Suicidas" y "Bardo" le antecede un epígrafe, es decir, un pequeño preludio que abre el tema del poema. No todos tienen título, pero todos tienen epígrafe. El contenido de los poemas, sin rima ni puntuación, se narra desde el yo poético de una madre que sufre la muerte de su hijo. En una especie de autoficción poética, Seligson da un costado del contexto de esa madre, que parece ser ella misma, para servir de correlato al resto de los textos de Simiente.

"Días de polvo" ubica a la mujer que narra lejos de su hogar original, "Estás tan lejos me dicen tan sola" (144), y ella escribe que no, que nunca lo suficientemente sola, que el mar tampoco está nunca solo, siempre poblado de seres. El día a día, el tiempo de nada o de polvo, no permiten que la soledad lo ocupe todo. Como sabemos, en los días que Seligson comenzó a pensar este libro, se encontraba en Israel, frente al mar. La segunda parte del poema deja de lado la cotidianidad, "la necia costumbre de procurarse víveres", que es la necia costumbre de vivir, para mostrarse con su único compañero de entonces:

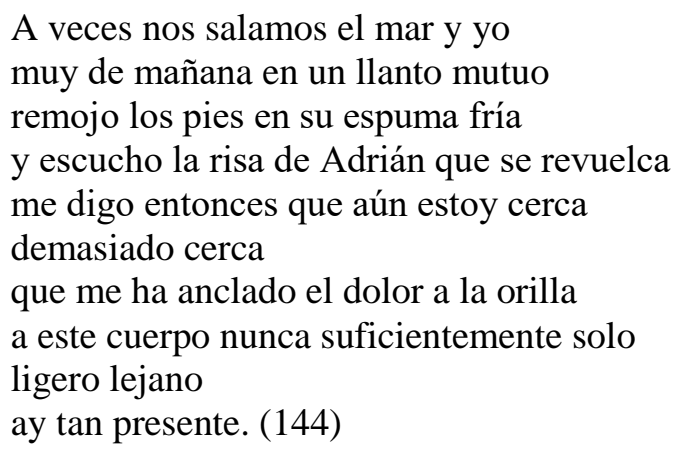

Este poema abre el libro, deja patente la pérdida, el dolor y la huída. Es apenas el inicio de un duelo que va a mostrarse en el resto de los textos a partir de una exploración de la vida propia, de personajes reales y de ficción, y de las situaciones que de alguna forma Seligson cree que llevaron a cumplir el designio de Andrés. La palabra simiente no solo alude a la semilla o brote que simbólicamente es el hijo, también refiere al origen, al comienzo, al regreso para buscar una especie de purificación que permita volver a empezar; a los "caminitos de luz" (147) que sigue hacia atrás y hacia delante en el tiempo. En "Oración del retorno", de Negro es su rostro, la escritora escribe: "Hacia ti Madre camino de nuevo firme la pisada" (72), y termina la oración pidiendo que queme todo lo que la ata: el dolor, los remordimientos, los

muchísimo, de ninguna manera, un inculto no puede leer nada. Cuánta gente me dice es que escribes muy difícil, es que no te entiendo, es que qué quisiste decir aquí. Un día me llamó un estudiante de letras que me dijo: «leí tus libros y hay cosas que no entendí y quisiera que me expliques». Le contesté, pues si no entiendes no leas ni escribas nada sobre mí, yo no tengo por qué explicarles nada, háganse de cuenta que estoy muerta. La literatura es de todos, menos de los ignorantes, por supuesto" (González Mateos, en línea). 
reproches, "quema las escorias que lanzan mi vuelo/y bendice Madre lo que aún me queda por andar..." (81). En esta idea, Seligson comentó en una entrevista:

"Una simiente es la semilla que siembras, la simiente espermática, es origen, génesis. Nunca le pongo nombre a mis libros pero en este caso el título fue espontáneo y surgió porque es un libro luminoso. Es simiente de luz y también de caos. El caos está lleno de semillas, simiente de la creación. Y es libro de luz porque, aunque suene paradójico, la muerte es la otra forma de la vida, la verdadera simiente, la luz". (Abelleyra: 2004, en línea)

Esa es la idea en el volver hacia la semilla, que lo contiene todo:

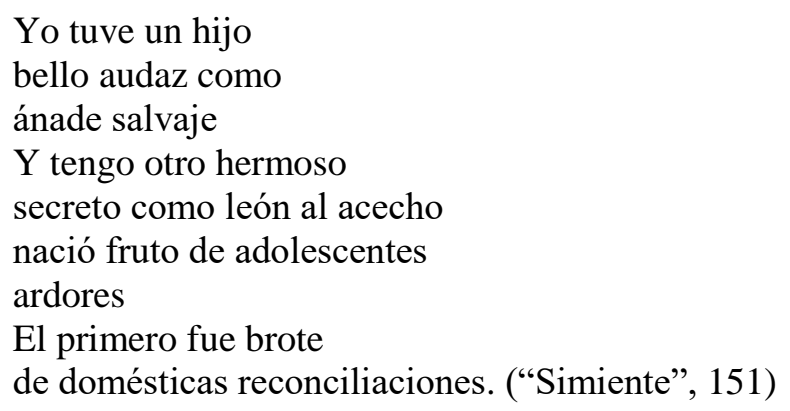

En una especie de racconto, el poema hace una retrospectiva para dar los antecedentes de vida que expliquen el final de la historia de Simiente. La mujer dice que tuvo dos hijos y agrega: "Yo he sido árbol/de sueños alborotados/y ambos crecieron sin nido/entre el bronco ramaje" (151). La descripción de sí misma, como un árbol poco dado al abrazo de las aves, es uno de los muchos versos que tratan de justificar una maternidad que al final, el yo poético teme, fue insuficiente. El poema termina de la siguiente manera:

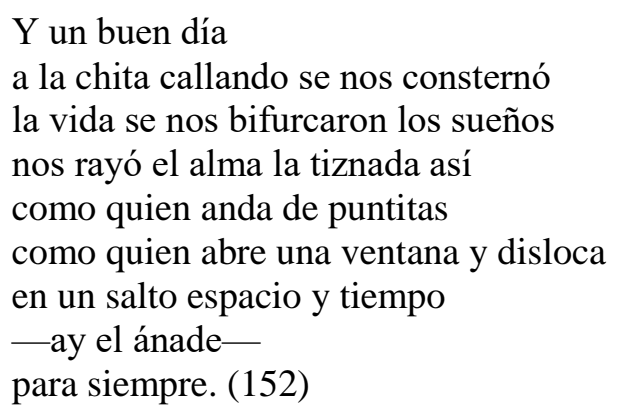

Después de que la primera parte del poema describe lo luminoso de la vida doméstica al lado de los hijos, en la segunda todo se ensombrece. La imagen aparece fracturada y el dolor domina estas líneas, que con el último verso - "para siempre" - se instala no solo en este poema, sino en el núcleo de todo el texto. El gesto del salto, como representación, inicia aquí y vuelve repetidamente en otros poemas; como si el movimiento último del hijo se prolongara a lo largo de ellos.

El verso libre de los poemas, sin signos de puntuación, enfrenta al lector a textos cargados de significados. Un mismo verso, encabalgado con el anterior o con el siguiente, incluso aislado, significa algo distinto cada vez. Simiente se organiza como un prisma de varias caras; esta estructura se ve reproducida en los poemas que, en esta analogía, son como cristales rutilantes. El orden que ocupan dentro del texto no da una narración lineal de los hechos, sino alguna de las caras de ese prisma, con la alternancia de los dibujos y textos de 
Adrián. De esta forma, cada poema agrega algún aspecto a la muerte del hijo: lo emocional, lo inexplicable o lo meramente anecdótico.

En "Funerales", el yo poético describe, con cierta ironía, la actitud curiosa, de "mirada falsa compungida" (159), de los asistentes a las exequias de su hijo. Los que van a tratar de completar una historia que no es clara para nadie, que pertenece al espacio "de lo incomprensible, irresoluble" (159). En este ámbito cae la historia de Nadine, la compañera que Adrián acuchilló cinco días antes de tirarse por la ventana. Días que pasó encerrado con el cuerpo, en un estado que, finalmente, lo empujó a terminar consigo también. ${ }^{8}$

Seligson no deja fuera esta pieza en el cúmulo de imágenes que van armando su historia fragmentada. "Ella, Nadine” comienza de la siguiente manera: “¿Por qué llegó tu destino/a buscar el cuchillo entre sus manos/solitaria huérfana hija de suicidas?” (163). Más allá del papel que tuvo Nadine (actriz, profesora de francés) en la vida de Adrián, los fragmentos literarios que entreteje hábilmente Seligson la señalan como la última hebra de la que pendía Adrián. La depresión lo empujó al crimen y éste a la autoaniquilación. Seligson los emparienta como dos personajes de otro mundo, condenados: "Demencia/ambos rondando los límites/ambos malabaristas transgresores" (163). Determinados a encontrarse, dos seres sin tierra firme: "y en la morgue/dos cuerpos desmoronándose:/Ella, ceniza solitaria/el otro, barro suelto..." (164).

Los tres poemas que siguen al de Nadine se dirigen al hijo para expresar el dolor por su pérdida. El yo poético, la madre, le pide que regrese, no como recuerdo, sino en su voz tangible: "Retorna/como sea que fuere/devuélveme tu voz" (172). En "Petición sumaria" le dice que necesita que sea él quien venga por ella, "no tardes [le pide] aunque tú tengas ya/frente a ti la eternidad" (185).

\section{No quiero tiempo más tiempo \\ para qué con el que tuve basta \\ lo demás se detuvo cuando partiste \\ ningún reloj marcará otra hora distinta \\ las manecillas de tu cuerpo en el aire \\ transformaron en suicidio \\ cualquier paso del tiempo... (185-186)}

Una vez más, el poema representa la imagen del salto, en este caso vinculado con la temporalidad. Por un lado, para el yo poético es un tiempo desbordado, que ya no quiere tener; por otro, es el tiempo que simbólicamente carga el cuerpo del hijo, girando en la caída y marcando con sus vueltas una temporalidad que se ha detenido, que ya no señala el paso del tiempo, sino la hora fija en que partió.

\footnotetext{
8 “Sobre el telón de fondo de esa obra se jugó otro drama que la escritora no rehúye contar en toda su crudeza: el suicidio de su hijo Adrián, actor, «un profesional de la representación, del arte de la repetición» según sus propios términos, después de matar a cuchilladas a su amiga Nadine. Adrián se quedó cinco días encerrado con el cadáver de su víctima y acudió a casa de su madre para, frente a sus ojos, lanzarse por la ventana y volar los once pisos que lo separaban de la tierra: «voló once pisos abajo en una inverosímil voltereta de acróbata impecable. Quien no lo vio jamás creerá que cayó ‘como si un Ángel lo hubiese sostenido en el aire', de espaldas sobre el piso del garaje sin dejar una sola gota de sangre derramada, o que manchara sus ropas». ¿Qué se podía añadir a este enigma clínico sino otras preguntas?: «¿Acaso nuestros afectos son sólo proyección de carencias infantiles? ¿Fui una madre desertora? ¿Me puse siempre a merced del objeto amado fuera o no correspondida?»» (Fabienne Bradu, en línea).
} 
Esther Seligson siempre hablaba francamente del episodio en el que murió su hijo. Si bien en entrevistas ${ }^{9}$ se refirió al hecho más de una vez con aparente calma, la experiencia que se despliega en Simiente está cargada de emotividad por las imágenes, a la vez brutales y bellas, con las que de ilustra el suicidio de Adrián:

Tus ojos eran sólo plegaria

tu mirada un rezo ardiente

Me dejabas en la carne

un mensaje a descifrar de por vida

mientras tu mano rápida leve

se extendía ala premonitoria

para alcanzar no sé qué invisible

corcel esperándote en el aire

más allá de la ventana (178).

Los dos últimos poemas aluden a la naturaleza del hijo según la voz poética; por un lado, el poema "Suicidas" incluye a Adrián en la serie de artistas que decidieron morir por cuenta propia; por otro, "Bardo", lo señala como poeta. Seligson dedica "Suicidas" "A Eloisa Leobardo Federico Beti Luis Isa Ana Irma Cesare Paul Virginia Bruno Primo Concha Florbela, entre otros" (189), en él los define como seres que exceden las dimensiones de su cuerpo, de la vida: "[...] de dónde/tanta sangre para un vaso tan estrecho" (189). Una de las formas con las que la escritora trata de explorar al hijo, de entenderlo, es mostrándolo como si perteneciera a una categoría particular de seres humanos. Por eso lo incluye en el grupo de otros suicidas que dejaron constancia de un espíritu artístico único, incapaz de adaptarse por completo a lo mundano. En este sentido, lo considera como a esos poetas, diferente y con una comprensión y sensibilidad por encima de las del resto. Lo que los lleva a vivir en constante angustia, siempre un paso más próximos a la muerte. Ese pie por delante, hacia la muerte, supone en el presunto suicida una existencia en el medio, es decir, una que en su transcurso no se decide completamente ni por la vida ni por la muerte.

El último poema, "Bardo", refuerza esta idea. Por un lado bardo es un poeta, pero por otro, Seligson le dice al lector en una nota a pie de página que "Bardo: [es un] término del budismo tibetano que significa literalmente entre dos, intervalo. Designa las diferentes encrucijadas que atraviesa la conciencia en todas sus circunstancias existenciales. Se aplica en general al intervalo de tránsito entre la muerte y el renacimiento" (196).

Cuando ya no hubo nada que hacer

quise tocar tu sombra

sombra de muerte en los párpados

-Vete en paz, dije

[...]

como barco navegando sin orillas

-Boga en paz, murmuré

[...]

\footnotetext{
${ }^{9}$ En una entrevista con Sandra Licona a la pregunta "Pero la estancia en Jerusalén ha sido la más catártica, ¿no?”, responde: "No sé si tú sabes que yo me fui de aquí porque murió mi hijo Adrián. Saltó de aquí, de esa ventana que ves al fondo. Yo lo vi volar. Comprenderás que una experiencia de ese género, aunque yo no crea en la muerte, te tiene que cambiar... No sé si decirte que esos seis años han sido los más catárticos u otra más de mis catarsis, porque soy escorpión con Plutón en el ascendente, y las catarsis, quiera o no, ahí están" (2006, en línea).
} 
Tocarlo así una última vez rozar con mis dedos su frente el borde de sus cabellos como limpiándole no sé qué hebra todavía que lo atase y retuviera

-Suelta todo, imploré la Gran Liberación es el camino ahora concluyó la errancia inseparable del vacío es la luz

Mi voz se hizo canción de cuna le abría un espacio de pureza al niño cuyo cuerpo yacía hombre entregado a su destino... (196-198)

El poema recrea la imagen de la madre frente al cuerpo del hijo muerto. El título y la nota que lo explica dirigen la lectura que Seligson quiere que hagamos. No es solo la despedida, apacible, al hijo que ha partido, sino la representación del instante de transición en el que la vida y lo que se es se transforman en algo más. Si bardo alude, según el texto, a un entre dos, entonces el poema sucede justo en ese intervalo de tiempo, diminuto y de tránsito.

En el juego del actor, en su padecer, la identidad parece siempre pospuesta; no más densa que ese otro cuerpo que se elabora en la escritura y que supone una representación que es "el trabajo infinito del duelo de lo absoluto" de esa presencia (Marin, 2009: 139). En el "absoluto de un imaginario", la representación se prolonga, se difiere entre paréntesis, en "el guión escrito" (165) entre madre e hijo, en epígrafes y en poesía (Romano, 2017: 96).

Este poema, en el tema de vida/muerte, pone en imágenes la representación de lo híbrido sobre la que se sostiene Simiente. La transmutación que lleva de la vida a la muerte queda suspendida en un instante que lo contiene todo, tanto una condición como la otra. Bardo es el hijo, él mismo como poeta y como un espacio del entre. Él mismo lleno de intervalos, de identidades intermitentes entre el actor y el hombre, que trata de explorar la madre con su escritura. El poema representa el tiempo de soltar, de dejar atrás el mundo para dirigirse, como si aún se tuviera voluntad, a otra dimensión. No por nada "Bardo" es el último poema del libro, antes del "Epílogo".

Lo hídrido textual se ubica dentro de la línea del pensamiento posmoderno que relaciona diversos discursos a través de rizomas ${ }^{10}$ que los vinculan infinitamente. El texto de

\footnotetext{
${ }^{10}$ En "Introducción: Rizoma", Gilles Deleuze habla de los "caracteres principales de un rizoma: a diferencia de los árboles y sus raíces, el rizoma conecta cualquier punto con otro punto cualquiera, cada uno de sus rasgos no remite necesariamente a rasgos de la misma naturaleza; el rizoma pone en juego regímenes de signos muy distintos e incluso estados de no-signos" (2004: 25). En esta misma línea, en Crítica y clínica, Deleuze agrega que "escribir es un asunto de devenir, siempre inacabado siempre en curso, y que desborda cualquier materia vivible o vivida" (1996: 5). Queda de relieve que, en el pensamiento de Deleuze, la escritura no es una inscripción fija, sino un movimiento continuo y las derivaciones de sentido que ese gesto supone. Esas bifurcaciones son los derroteros por donde la letra decide correr, diseminada, para alcanzar siempre distintos puntos significantes. Para este artículo es importante la referencia a una forma de escritura que desplaza las fronteras, no solo de género, sino también de sentido. En las citas de Deleuze reconozco, por un lado, el proceder formal de Seligson, al entrelazar el contenido semántico de los distintos registros de su texto; y por otro, la idea que estrecha escritura y vida para generar un sentido "inacabado" y "desbordado".
} 
Seligson, y su obra en general, se organiza sobre el principio estructural de una literatura transtextual, es decir, una letra diversa, viva, que está en un continuo de paso a. Es un discurso que no se detiene en la ficción, sino que vive, muy activo, en los límites — en los márgenes ${ }^{11}$ — de otros discursos y distintos géneros. De ahí que esta forma de escritura permita explorar los costados de una realidad desde miradas - textos — variantes.

\section{Prosa autobiográfica: cartas, diarios y letra suelta}

Los textos que por su apariencia — no tanto por su organización sintáctica y léxica— podrían denominarse como prosa, se alternan con los poemas que antes hemos expuesto. Son textos sin puntuación, más complicados de leer que los poemas, con los que Seligson se dirige a un hijo que carece de consistencia y que en la letra se va creando y a la vez desdibujando en un vaivén de frases que no consiguen darle peso.

La falta de puntuación obliga a leer con más detenimiento. Las combinaciones de sentido que se pueden hacer, según se lea haciendo pausas en un momento u otro, son muchas. Al mismo tiempo, se marca un ritmo acelerado en el texto, de tal forma que la voz que habla parece inquieta, dispersa entre los recuerdos y las preguntas alrededor de Adrián.

En el primer texto, Seligson explica cómo le llegaron las cartas, hojas de diario y dibujos del hijo que completan Simiente:

[...] preñaste con las semillas prófugas de tu música interna muchos cuadernos y hojas sueltas que una noche - ¿supiste acaso que te despedías? - con paciencia inusitada desplegaste para mí lado a lado sobre mi mesa de trabajo una por una tantas asignaturas pendientes conocí de tu vida materiales de alta tensión infortunios insospechados en mi candor de madre tu histrionismo surco rebelde enardecido infierno sin remisión la locura al borde [...] mis ausencias quebraron los puentes "Te necesité, madre, y otra vez no estabas." (147)

Como se dijo, una de las líneas temáticas más importante en Simiente, quizás la más nutrida, es la de la culpa. No solo por frases como la última de la cita anterior, sino incluso por la estructura misma que representa una especie de andar errático en el que la madre va de un discurso a otro para tratar de entender al hijo. La configuración de la obra responde a esta búsqueda inquieta y señala, a la vez, tanto el fluir de la voz de la madre — con cambios de tono de texto a texto - como el cuerpo del hijo, a veces en la sombra otras en la luz, según la perspectiva desde la que, también por el tipo de texto, puede ubicarse el lector. Este ir y venir de formas y discursos, así como el tratamiento particular de cada uno, transmite la desazón y el trance bajo los que fue concebido el libro. La autora comenta en una entrevista:

Simiente es sui generis. No tiene nada que ver con lo que había hecho. Supongo que alguien que conozca lo que escribo podría reconocerme; para mí es un parteaguas definitivo y por supuesto no habrá otro ni parecido ni cercano. Lo escribí en un estado de mediumnidad y alucinación de seis semanas. Era como un dictado. Supongo que hay muchas obras de este estilo, con toda la humildad que no tengo, como pudo haber escrito Rimbaud Una estancia en el infierno. Es algo que no tiene que ver con tu ego ni contigo como persona, en el sentido

\footnotetext{
11 "Márgenes" en el sentido en el que Jacques Derrida concibe el término, es decir, por un lado, como un espacio elástico, descentrado, y por otro, como una forma de acción desde lo liminar. Manuel Asensi explica la versatilidad del margen derridiano: "El marco, parergon, acude a una necesidad planteada por la obra «interior» tanto en el sentido de la necesidad de una delimitación como en el de una «falta». [...] la palabra parergon ya no significa ni totalmente exterior ni totalmente interior, esencia y accidente sin síntesis" (1995: 30).
} 
griego de la palabra y en el sentido jungiano. Tú eres un canal sobre el cual se está vertiendo algo que tiene la urgencia de ser expresado. Y que se vierte a borbotones frente al mar. ¿Qué puedes entender entre una ola y otra? Es un escrito de tormenta donde no hay pausa pero sí respiración. Y el mar sí se queda callado en algún momento. (Abelleyra, 2004)

Adrián, el protagonista/personaje-dibujo/voz ausente de este libro, deja páginas de su diario en las que él mismo trata de reconstruirse. Los facsímiles de sus escritos, que Seligson integra al texto, dan cuenta de un personaje que, por medio de citas de otros autores y de sus propias reflexiones, trata de desentrañar el sentido de la vida y su lugar en ella. Las cartas a la madre dejan ver una relación más bien distante en la que la figura materna tiene un peso central en la vida de Adrián.

Antes de "Bardo", es decir, del último poema del libro, Seligson incluye la copia de una carta escrita por Adrián y dirigida a ella. Tiene fecha del 28 de noviembre de 1979, cuando Adrián tenía 13 años. Comienza de la siguiente manera: "Esta mañana no fui a la escuela porque tengo catarro, no tengo calentura, pero una fuerte tos. Te agradezco que me facilites la lectura de tus cartas escribiéndome a máquina" (194). Es una carta larga en la que prevalece un tono cuidado, lleno de respeto y distancia a la madre ausente; le cuenta lo que ha hecho, lo que lee. Trata de construir la imagen de un niño a la medida de las aspiraciones de su madre. Más adelante dice la carta: "Te comprendo perfectamente, con respecto a que te quedes más tiempo allá; por una parte me gusta más que estés allá haciendo lo que siempre has deseado y estando contenta porque no vale la pena que estés aquí y que estés haciendo corajes y que, cosa que ni a ti ni a mí nos gusta, estar en conflictos tú y yo" (194). ${ }^{12}$ La relación de Seligson con su hijo no es irrelevante, en este caso, para tratar de explicar la literatura híbrida de la autora. Para Adrián, su madre es una especia de alter ego; un modelo de conducta, inteligencia y talento difícil de alcanzar. Los altos estándares que la propia Seligson impone a su escritura son los que exigen en la gente con la que se vincula. Las cartas dan cuenta de esta relación y permiten entender la construcción literaria de Simiente. En los poemas, el hijo es la contraparte de la madre, son un mismo cuerpo escindido —en vida y muerte- que se separa apenas por ese instante indefinible entre el ser y el ya no ser. La hibridez textual, como se ha mencionado, se ramifica en los temas y en la construcción intrincada que vincula la poesía, la prosa y los dibujos. En unos y otros se encuentran ecos de cada referencia textual; entrar en cualquiera de estas formas lleva al vértigo de la puesta en abismo: la caída en un texto que lanza al lector a la representación visual — en el dibujo — de aquello que representa. En este sentido, se puede afirmar que el carácter híbrido de Simiente se sostiene en el recurso performativo - teatral— que tanto ensayó Seligson y que forma parte de su propuesta estética.

Los textos de Seligson se tejen alrededor de un núcleo hecho de la culpa que los tímidos reproches del hijo ponen en ella. Que sea él quien deja frente a la madre, los textos que lo representan es un gesto que ella tratará de interpretar tanto como a los papeles. Él se presenta como representación, y después de muerto, como la única que puede ser leída. Las hojas extendidas sobre su mesa de trabajo significan una empresa más de refiguración para la escritora. En la prosa poética que se encuentra en Simiente, Seligson alude a los dibujos y

\footnotetext{
${ }^{12}$ Más adelante escribe Seligson: "no poder nunca más consolarte consolarnos como cuando niño tu pesadilla donde clavabas las tijeras en mi espalda para impedir que me fuera otra vez" (169).
} 
textos de Adrián. Crea hilos de sentido que van hilvanando los distintos registros textuales del libro y que subrayan que no es una especie de collage de escritos e imágenes, sino una obra con canales discursivos que conectan sus distintos planos; es decir, un texto congruente, correctamente estructurado y con profundos estratos de sentido.

En aras de estas relaciones, Seligson escribe en la prosa: "te dibujabas a tinta blanco y negro color a veces sin proporciones cabeza burlona ojo sarcástico sonrisa juguetona demasiada alma no te cabía largos brazos largas piernas [...] preguntándote quién ser o qué no ser" (149). En la medida en que ella trata de (re)conocer al hijo, se reencuentra con ella misma y se descubre como madre de Adrián. Dialoga con sus vestigios, con la letra y los trazos que le ha heredado como último gesto a interpretar. Lo lee, lo mira en sus autorrepresentaciones, lo engulle y lo expulsa en su escritura, en la de él: "me adentro en el insomnio de tus insomnios [...] cuándo dónde cómo adquirimos esa medida tras la que andamos en pos a contracorriente carrera imparable pez máscara «el silencio en un soplido se apaga»" (149).

La escritura funciona en este caso como un proceso en el que la madre quiere representar al hijo ante el lector. Lo contiene en su escritura, como alguna vez lo contuvo en las entrañas, para configurarlo de nuevo. Lo que resulta en una máscara de Adrián hecha de retazos de papel, tinta y trazos infantiles, que lo dejan "expuesto entre paréntesis" (150), en la visión de la madre que le dice: "enredabas a propósito el hilo para (no) salir del laberinto" (150). La figura de Adrián que se va construyendo es una hecha de contradicciones, de múltiples rostros — los del actor — que son y no son él; hecho del "amor a la propia paradoja" (150) para "destruirse por el puro reto de reconstruirse" (153). El "no" entre paréntesis incluye y excluye al mismo tiempo, ubica, nuevamente, en el entre de un espacio diluido que disemina, deconstruye la identidad de Adrián.

Seligson lo cita en su escritura: “«mi único afán está en abarcarme sin remilgos, en buscar la vía de la implosión, entrar por un corredor de desesperación que obligue a vomitar las tripas sobre las que patéticamente vamos a caer y cuyo olor nauseabundo atraerá aves de rapiña, hormigas y perros callejeros» ¿es ésa la voz del pequeño hijo tierno?" (153), ese que suplica: "dame tiempo, madre, a veces no me siento real" (155).

Adrián, el héroe de estas páginas, es un personaje que se dibuja a sí mismo escindido desde su escritura y sus dibujos, y que no puede ser representado en la escritura de Seligson sino como un ser fragmentado:

cómo completar la imagen total de esos fragmentos que cada quien tenemos de ti agente vendedor portafolio negro en mano y que después se llenó con tus hojas dibujadas titiritero actor gourmet aprendiz de brujo de artes marciales cómico de la legua guitarrista improvisado viajero espadachín homicida pacheco versificador cinéfilo ciclista pendenciero apacible alucinado amoroso vengativo tierno fumador de faritos amante fiel promiscuo leal convenenciero dandy despilfarrado amiguero melómano [...] estirpe de suicidas que parten con cuchillo las espesuras de la razón y la lógica. (175-177)

\section{La voz de Adrián: los dibujos}

La aparente fragmentación de Simiente es un artificio para configurar un texto que, como manifestación estética, muestre un proceso de representación en el que sus planos estructurales dialoguen con los temáticos. Los distintos registros discursivos, si bien no 
responden a la forma ortodoxa del género al que en apariencia pertenecen, sí están organizados conforme al orden del texto en conjunto. Cada una de las partes que lo configuran - poemas, prosa-poética, cartas, facsímiles, dibujos, epígrafes - cumple una función particular y se comunica entre sí, se difiere y refleja en el siguiente. El tema Adrián, su muerte, la culpa - cruza transversalmente todos los tipos de escritura que conviven en Simiente; a su vez, cada uno de ellos se vincula estructuralmente con los otros. La línea final de cada texto en prosa, por ejemplo, es la primera del siguiente; entre ellos, siempre hay alguna carta, poema, facsímil y dibujo que se "completan" entre sí. Esta forma de ir encadenando los discursos, a pesar de ser de distinta factura, va uniendo eslabones de sentido que se fragmentan en muchos más. Así como se puede leer de diversas maneras un texto que no tiene puntuación, lo mismo sucede con las frases que parecen idénticas, pero que al moverse de lugar y de género ya no tienen la misma carga semántica. No solo en el caso que arriba mencioné, en el que las líneas se repiten al final y al comienzo de la prosa, sino también en los fragmentos del diario de Adrián que cita Seligson en sus poemas, o bien en las cartas de las que extrae partes o incluye en su totalidad. El trazo del hijo, entonces, significa algo en el dibujo o en las líneas de su letra en los facsímiles, y otra cosa en la recuperación que hace de ellos Seligson en su escrito.

Como ya se ha dicho, "Bardo" es el último poema antes del "Epílogo"; entre el poema y el texto en prosa postrero, está el facsímil de la carta que a los trece años le escribe Adrián a su madre. Por otro lado, el último texto en prosa no es de Seligson, sino otra carta de un Adrián adulto. Así, antes del poema "Bardo", en el que lo despide su madre, se tienen dos versiones — en las cartas - no solo de Adrián, sino de la relación con ella. La necesidad que el niño de trece años refleja tímidamente, se muestra viva en el adulto de la carta que transcribe Seligson: "El viernes estuve en tu casa [...] me senté en la sala a fumarme un cigarrito, a ver la casa, las plantas, a pensarte, a extrañarte sin más" (192). El tono no es severo, como en la carta del niño, sino más tranquilo. Al final de esta carta, Seligson elige poner uno de los dibujos de Adrián, esos que ella considera "autorretratos", en el que se ve a un chico sonriendo, que marcha hacia algún sitio de paseo.

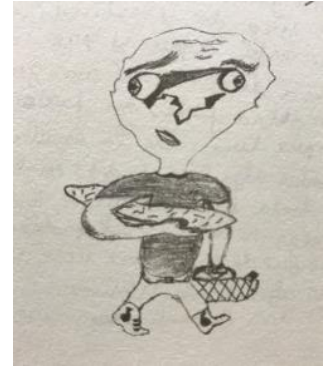

La imagen, en concordancia con las coplas de la canción con que termina su carta, dan una idea de alegría. Después viene el facsímil de la carta del niño abandonado. La otra cara, la que precede al adulto sosegado en la casa de la madre. La letra pequeña, muy apretada, parece querer decir mucho en poco espacio. En letra mucho más encogida, firma: "Muchos besos de tu hijo que te extraña, Adrián" (195).

El poema "Bardo" tiene dos dibujos; el primero parece ilustrar los versos que dicen: "Yacía su cuerpo tendido/como vela hinchada en alta mar/como barco navegando sin orillas" (196): 


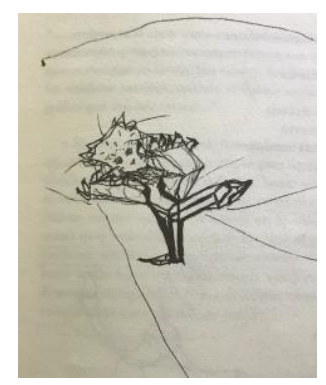

El segundo dibujo, ilustra al "espadachín homicida", al que el yo poético le dice: "Suelta todo [...] la Gran Liberación es el camino ahora" (198):

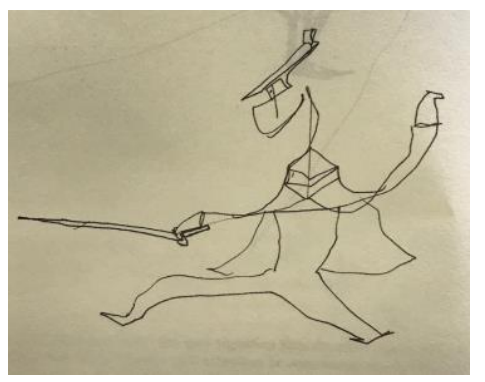

Según Gadamer, en el arte como en el juego, algo está puesto en marcha, algo está sucediendo. Esto alude al hecho de que la representación artística es una autorrepresentación; su organización ya implica un continuo estarse haciendo a sí misma (2007: 146). En este sentido, Simiente es un escrito que, al estar armado con muchos registros, parece organizado en una espiral de sentido que ilustra cómo se vinculan sus planos. Un espacio empuja a otro y a otro sucesivamente, de tal forma que lo híbrido, en este caso, responde a una obra que encuentra su fundamento en esa armazón múltiple de autorreflexión.

\section{Conclusiones}

En el "Proemio", como si fuera una continuación del poema "Oración del retorno", el vocativo madre sirve al yo poético para abrir su texto; uno en el que ese yo, a su vez, se va a explorar, implícitamente, como madre: la que apela a Adrián. Se detiene en este comienzo para mirar atrás, al origen protector, y decirle a la Madre frente a la inmensidad del mar: "A orillas del mar, Madre, pusiste margen a mi pena" (143). Le dice que es ella quien la puso frente al dolor, y es frente al mar que recuerda la mirada y la "radiante sonrisa" del hijo antes de saltar. El "Proemio" tiene dos párrafos, el primero carga la imagen del hijo, "dulce, juguetona, antes de cerrar los ojos" (143); en el segundo, ella se ve frente al mar, donde sabemos - se gesta Simiente.

El "Epílogo" se abre con el fragmento de una carta de Adrián en el que destaca la idea de que él y su madre mantendrán una conversación sin fin: “....aunque esta carta haya concluido, imaginemos que nuestra comunicación y nuestra correspondencia son una larga historia" (199). El último párrafo, que es el que cierra la obra, describe el momento en que Adrián, en el departamento de su madre, salta por la ventana desde el piso once. Igual que en "Bardo", en este texto se subraya el espacio y momento temporal que separa la vida de la muerte. Se congela el segundo del impulso que lleva a cruzar el umbral de la ventana. Ese 
umbral y el hecho de atravesarlo se vuelven simbólicos. La habitación es la antesala que contiene a la madre o que - como dice Adrián en su carta - es la madre misma. El salto por la ventana es un salirse de ella, en una especie de nuevo parto en el que se lanza hacia otro tipo de existencia. Esto, en relación con la espiritualidad de Seligson, también híbrida y múltiple, remite a una mutación, a un cambio de estado, de una forma a la transición de otra. Dar a luz, en este caso, ubica frente a la puesta en escena en la que Adrián, en "el impulso de [sus] piernas hacia arriba hacia afuera un resorte una pirueta arabesco" (199), decide atravesar el umbral de la ventana. "Toda la luz" es el entendimiento pleno de que la muerte es un comienzo.

Simiente es uno de los textos que mejor representa la intención de Esther Seligson por crear una escritura fuera de los cánones que definen los géneros literarios. Las posibilidades de juego textual le permiten explorar temas, así como formas de composición de la materia lingüística. Simiente contiene muchos de los intereses que desarrolla en su literatura en general, pero con la peculiaridad de que está escrita para Adrián, para encontrarlo; como ella dice: "Sin brújula me aventuro tras tus huellas entre papeles dibujos fotos" (188). Es decir, a partir de un registro biográfico, retoma una serie de formas de representación desde la cual arma un discurso híbrido. Las posibilidades significativas que se desprenden de esta simulación, cruzan los distintos niveles que lo conforman. Poesía, dibujo y prosa epistolar dan reflejos de sentido que construyen, en distintas líneas semánticas, una identidad y sus referencias. Este polimorfismo en el texto de Seligson le permite transgredir las reglas de los géneros que integra para desembocar en una propuesta de interés literario y valor estético. En este sentido, me parece que lo emotivo del texto y sus referentes biográficos no demeritan la calidad y cualidades de un escrito que, como todos los de Seligson, demanda un lector más activo.

Simiente se dirige a Adrián, y así, hacia el futuro; hacia el desarrollo de una escritura que está en búsqueda del cuerpo que corresponda con el nombre. Está a la zaga del que creyó su hijo, para descubrir que ese "peludo corazón pelirrojo", desde siempre, había sido habitado por demasiada luz.

\section{Bibliografía}

ABELLEYRA, Angélica: "Entrevista con Esther Seligson: «Simiente un escrito de tormenta»". La Jornada Semanal 478 (2 de mayo de 2004), versión digitalizada disponible en: http://www.jornada.unam.mx/2004/05/02/sem-abelleyra.html (fecha de última consulta: 16/10/2017).

ASENSI, Manuel (1995): "Estudio introductorio: La crítica del límite / El límite de la crítica". Teoría literaria y deconstrucción. Comps. Manuel Asensi. Madrid, Anthropos: 9-80.

BRADU, Fabienne: “Todo aquí es polvo de Esther Seligson". Letras Libres (28 de febrero de 2011), versión digitalizada disponible en: http://www.letraslibres.com/mexico/todo-aqui-espolvo-esther-seligson (fecha de última consulta: 16/10/2017).

DELEUZE, Gilles (1996): Crítica y clínica. Trad. Thomas Kauf. Barcelona, Anagrama. Versión digitalizada disponible en: http://www.medicinayarte.com/librosdigitales/oficina/biblioteca/critica_y_clinica.pdf (última consulta: 30/10/2017) 
DELEUZE, Gilles y Félix Guattari (2004): Mil mesetas. Capitalismo y esquizofrenia. Valencia: Pre-Textos.

GADAMER, Hans Georg (2007): Verdad y método. Salamanca, Ediciones Sígueme.

GONZÁLEZ MATEOS, Adriana: "Esther Seligson, hechicera nómada". Confabulario (Suplemento Cultural de El Universal) (31 de octubre de 2016), versión digitalizada disponible en: http://confabulario.eluniversal.com.mx/esther-seligson-hechicera-nomada/ (fecha de última consulta: 16/10/2017).

LICONA, Sandra: "Entrevista a Esther Seligson: «No sé qué es asumir el dolor»". El Universal (18 de julio de 2006), versión digitalizada disponible en: http://archivo.eluniversal.com.mx/cultura/49347.html (última consulta: 16/10/2017).

MARIN, Louis: “Poder, representación, imagen". Prismas. Revista de Historia Intelectual 13 (2009): 135-156.

MORAL ESPINOSA, Adriana del: "Esther Seligson: vencer al tiempo". La Jornada Semanal 781 (21 de febrero de 2010), versión digitalizada disponible en: http://www.jornada.unam.mx/2010/02/21/sem-adriana.html (fecha de última consulta: 16/10/2017).

NOGUEROL JIMÉNEZ, Francisca: "Híbridos genéricos: la desintegración del libro en la literatura hispanoamericana del siglo XX”. Rilce XV/1 (1999): 239-250.

ROMANO HURTADO, Berenice (2017): "De persona y personajes: dramaturgia y representación en la escritura de Esther Seligson". Esther Seligson. Fugacidad y permanencia. Eds. Luzelena Gutiérrez de Velasco Romo y Ana Rosa Domenella. México, Universidad Autónoma de México: 87-101. En imprenta.

RYAN, Marie-Laure (1991): Possible Worlds, Artificial Intelligence and Narrative Theory. Bloomington/Indianapolis, Indiana University Press.

SCHMITT, Arnaud (2014): "La autoficción y la poética cognitiva". El yo fabulado. Nuevas aproximaciones críticas a la autoficción. Ed. Ana Casas. Madrid / Frankfurt am Main, Iberoamericana / Vervuert: 45-64.

SELIGSON, Esther (2010): Negro es su rostro. Simiente. México, Fondo de Cultura Económica.

YANIRETH, Israde: "Traza Seligson sonrisa de Buda". Fondo de Cultura Económica. com (18 de septiembre de 2007), versión digitalizada disponible en: http://www.fondodeculturaeconomica.com/editorial/prensa/Detalle.aspx?seccion=Detalle\&id _desplegado=9995 (última consulta: 08/05/2017).

(C) Berenice Romano Hurtado

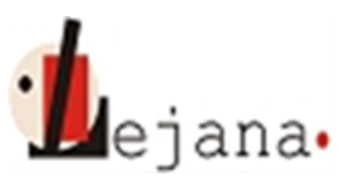

http://ojs.elte.hu/index.php/lejana

Universidad Eötvös Loránd, Departamento de Español, 1088 Budapest, Múzeum krt. 4/C 